\section{Kidney Blood Pressure Research}

\title{
Clinical Correlates of Ambulatory Blood Pressure Phenotypes at a Tertiary Care Hospital in Turkey
}

\author{
Siyar Erdogmus Sim Kutlay Zeynep Kendi Celebi Tolga Aydın \\ Damla Ors Sendogan Gizem Kumru Kenan Keven Gokhan Nergizoglu \\ Sehsuvar Erturk Sule Sengul
}

Ankara University School of Medicine, Department of Nephrology

\section{Key Words}

Ambulatory blood pressure monitoring - Cardiovascular risk - Hypertension - Masked hypertensive $\cdot$ Sustained hypertensive $\cdot$ Sustained normotensive $\cdot$ White coat hypertensive

\begin{abstract}
Background/Aims: Hypertension and its complications are major public health issues worldwide due to their association with high cardiovascular morbidity and mortality. Despite significant progress in health, the prevalence of hypertension is increasing. Ambulatory blood pressure monitoring (ABPM) is becoming increasingly important for the management of hypertension. In this study, we aimed to investigate the clinical and laboratory correlates of ambulatory blood pressure (ABP) phenotypes at a tertiary care hospital in Turkey. Methods: The characteristics of 1053 patients were retrospectively obtained from the hospital database. Hypertension was defined as patients with office blood pressure (BP) $\geq 140 / 90 \mathrm{mmHg}$ and/or previously diagnosed hypertension and/or the use of antihypertensive medication. According to the office BP and ABPM results patients were identified namely: (1) sustained normotensive (SNT) patients (both office BP and ABPM were normal), (2) sustained hypertensive (SHT) patients (both office BP and ABPM were high), (3) masked hypertensive (MHT) patients (office BP were normal, but ABPM were high), (4) white coat hypertensive (WCHT) patients (office BP were above limits, but ABPM were normal). Results: A total of 1053 patients were included to the study (female/male: 608/445 and mean age $55 \pm 15$ years). The mean age of patients with hypertension was significantly higher than without hypertension $(p<0.0001)$. Hypertension was more frequent in females $(p=0.009)$. The rates of history of diabetes mellitus (DM), hyperlipidemia ( $\mathrm{HL})$, and chronic kidney disease (CKD) were higher in patients with hypertension $(p<0.0001)$. Among patients with hypertension $(n=853,81 \%)$, ABPM results showed that 388 (45\%) of patients had SHT, 92 (11\%) had MHT, and 144 (17\%) had WCHT, whereas 229 (27\%) had SNT. Patients with MHT were significantly older than patients with SNT $(p=0.025)$. The prevalence of SHT was higher in men than in women, whereas the prevalence
\end{abstract}




\section{Kidney \\ Blood Pressure Research}

of WCHT was higher in women than in men $(p<0.0001)$. There was no significant difference between 4 groups with regard to body mass index $(p=0.142)$, a history of DM $(p=0.189)$ and smoking status (self-reported) $(p=0.306)$. Patients with SHT had the highest prevalence of history of hypertension, $\mathrm{HL}$ and CKD $(\mathrm{p}<0.0001)$. Among patients without hypertension, 26 (13\%) of patients had MHT and none of those patients was on antihypertensive treatment. Conclusion: Potential usages of ABPM in Turkey may include screening of high risk individuals who have traditional cardiovascular risk factors. It also provides clinicians valuable information on abnormal ABP phenotypes. Future studies are needed to clarify the risk factors of different $A B P$ phenotypes and to evaluate the role of $A B P M$ on detection and control of hypertension.

\section{Introduction}

Hypertension is an important public health issue worldwide. The prevalence of hypertension is increasing and it is predicted to reach 1.56 billion adults in 2025. However, hypertension is also frequently preventable risk factor of stroke, cardiovascular and kidney disease [1]. High blood pressure is the leading single risk factor for global disease burden and annually 9.4 million deaths have been attributed to effects of hypertension [2]. In 2003, the data collected from the prevalence, awareness, treatment and control of hypertension in Turkey (PatenT) study showed that the prevalence of hypertension among Turkish adult population was $31.8 \%$ [3]. Subsequently, there was no significant change the prevalence of hypertension at PatenT 2 study conducted in 2012, but the rates of awareness, treatment, and control of hypertension partially improved in our country [4]. Accurate measurement of the blood pressure (BP) is very important in the diagnosis and effective management of hypertension. Compared with conventional BP measurements, ambulatory blood pressure monitoring (ABPM) provides an insight individual BP phenotypes and it is more closely related to target organ damage and cardiovascular risk $[5,6]$. In this study, we aimed to investigate the clinical and laboratory correlates of ambulatory blood pressure (ABP) phenotypes at a tertiary care hospital in Turkey.

\section{Materials and Methods}

\section{Study population}

The study was conducted in accordance with Declaration of Helsinki and approved by Ankara University School of Medicine Ethical Committee for Clinical Studies. Patients who were older than 18 years and had adequate 24-hour (24-h) ABPM recordings (at least 70\% of measurements were satisfactory) were included in the study. Patients with known end-stage kidney disease requiring dialysis (48 patients) and inadequate 24-h ABPM recordings (57 patients) were excluded.

\section{Data collection}

Data were retrospectively analyzed from 1053 patients who had 24-h ABPM at Ankara University School of Medicine, Department of Nephrology, Hypertension Laboratory between January 2012-December 2016. The clinical characteristics and laboratory results of all patients were obtained from the hospital database. Clinical features including age, gender, height, weight, body mass index (BMI), smoking status, salt intake, office BP measurements, use of antihypertensive medication and comorbid conditions, were recorded. For laboratory values, serum creatinine and estimated glomerular filtration rate (eGFR) were determined. The eGFR was calculated using a 4 variable modification of diet in renal disease [7].

Antihypertensive drugs were classified as angiotensin-converting enzyme inhibitors (ACEi), angiotensin receptor blockers (ARBs), calcium channel blockers (CCBs), central acting agents (CAAs), $\alpha$-blockers, $\beta$-blockers and diuretics. The single-pill combinations were comprised ACEi + diuretics, ARBs + diuretics, ACEi + CCBs and ARBs + CCBs. 


\section{Kidney Blood Pressure Research}

Kidney Blood Press Res 2018;43:690-700

\begin{tabular}{l|l}
\hline DOI: $10.1159 / 000489742$ & (C) 2018 The Author(s). Published by S. Karger AG, Base
\end{tabular}

Published online: 16 May, 2018

www.karger.com/kbr

BP measurements and definitions

All patients had office BP measurements and 24-h ABPM. Office BP measurements were taken using after 5 min of rest in a sitting position, using an oscillometric automatic sphygmomanometers, with a suitably sized cuff based on the circumference of the upper arm. Before the BP measurements, none of the patients had alcohol consumption, cigarette smoking, coffee or tea intake and exercise for at least 30 min. If the reading was higher in one arm, that arm was used for the following measurements. At least three consecutive BP measurements were obtained, with a time interval of at least 5 min between each measurement according to the recommendations of the European Society of Hypertension. If the difference between last two measurements was less than $5 \mathrm{mmHg}$, the arithmetic mean of the second and third BP measurements was noted as the office BP [8].

The 24-h ABPM was performed using a Spacelabs 90207 device (Spacelabs Inc., Redmond, Washington, USA). Patients were informed about the device and the procedure. They were told to maintain normal daily activities but to avoid from heavy exercise and to stay immobile at the time of cuff inflation. The patients were asked to provide information about diaries, including awake and sleep time, the times of drug ingestion and meals. Measurements were made between 07:00 and 23:00 (daytime) at $30 \mathrm{~min}$ intervals and between 23:00 and 07:00 (nighttime) every at 30 min intervals. Thus, the average systolic and diastolic BP, heart rate and mean BP were obtained for 24-h day and nighttime.

Hypertension was defined as an average office systolic blood pressure (SBP) of at least $140 \mathrm{mmHg}$, average office diastolic blood pressure (DBP) of at least $90 \mathrm{mmHg}$ and/or previously diagnosed hypertension and/or the use of antihypertensive medication. According to the 24-h ABPM and office BP results patients were separated into 4 groups: (Group 1) sustained normotensive (SNT) patients (office SBP/DBP $<140 / 90$ $\mathrm{mmHg}$ and 24-h average SBP/DBP $<130 / 80 \mathrm{mmHg}$ and daytime average SBP/DBP $<135 / 85 \mathrm{mmHg}$ and nighttime average SBP/DBP $<120 / 70 \mathrm{mmHg}$ ), (Group 2) sustained hypertensive (SHT) patients (office SBP $\geq 140 \mathrm{mmHg}$ and/or DBP $\geq 90 \mathrm{mmHg}$ and 24 -h average SBP $\geq 130 \mathrm{mmHg}$ and/or DBP $\geq 80 \mathrm{mmHg}$ and/or daytime average SBP $\geq 135 \mathrm{mmHg}$ and/or DBP $\geq 85 \mathrm{mmHg}$ and/or nighttime average SBP $\geq 120 \mathrm{mmHg}$ and/ or DBP $\geq 70 \mathrm{mmHg}$ ), (Group 3) masked hypertensive (MHT) patients (office SBP/DBP $<140 / 90 \mathrm{mmHg}$ and 24-h average SBP $\geq 130 \mathrm{mmHg}$ and/or DBP $\geq 80 \mathrm{mmHg}$ and/or daytime average SBP $\geq 135 \mathrm{mmHg}$ and/or DBP $\geq 85 \mathrm{mmHg}$ and/or nighttime average SBP $\geq 120 \mathrm{mmHg}$ and/or DBP $\geq 70 \mathrm{mmHg}$ ), (Group 4) white coat hypertensive (WCHT) patients (office SBP/DBP $\geq 140 / 90 \mathrm{mmHg}$ and 24-h average SBP/DBP <130/80 $\mathrm{mmHg}$ and daytime average SBP/DBP $<135 / 85 \mathrm{mmHg}$ and nighttime SBP/DBP $<120 / 70 \mathrm{mmHg}$ [9].

Compared with daytime BP values, more than $10 \%$ decline in BP during the night was defined as dipper and at least less than $10 \%$ decline in BP during the night was defined as nondipper. Reverse dipper was defined nighttime BP values higher than daytime BP values [9].

\section{Statistical analysis}

SPSS 16.0 version (SPSS Inc., Chicago, IL, USA) was used for statistical analysis. All values are shown as mean \pm standard deviation or as a case number. Demographic parameters differences between two groups were analyzed using 2-sample t test or Mann-Whitney U test. Parameters differences among 4 groups were examined using an ANOVA variance analysis test. For post hoc analysis of non-normally distributed variables, Bonferroni corrected Mann-Whitney U test was used. Categorical variables were evaluated using Pearson's chi-square or Fischer exact tests. Results were considered statistically significant for $\mathrm{P}<0.05$.

\section{Results}

\section{Characteristics of patients}

The characteristics of the study population $(n=1053)$ are given in Table 1 . Requests for ABPM were made from outpatient clinics of nephrology $(n=590,56 \%)$, neurology $(n=254$, $24.1 \%)$, internal medicine $(n=81,7.7 \%)$, geriatrics $(n=34,3.2 \%)$, endocrinology $(n=28$, $2.7 \%)$ and cardiology $(n=66,6.3 \%)$. They were $608(58 \%)$ women and $445(42 \%)$ men. The mean age was $55 \pm 15$ years (range, $18-90$ years) and mean BMI was $28 \pm 5 \mathrm{~kg} / \mathrm{m}^{2}$. The rates of history of hypertension, diabetes mellitus (DM), hyperlipidemia (HL) and chronic kidney disease (CKD) among the entire patients were 66.7, 19.2, 30 and 23\%, respectively. 


\section{Kidney Blood Pressure Research}

More than half of the patients were using antihypertensive medication. A total of 449 (43\%) patients were dipper, 444 (\%42) were nondipper, and 160 (15\%) were reverse dipper. The mean office SBP was $140 \pm$ $20 \mathrm{mmHg}$ and mean office DBP was $87 \pm 25 \mathrm{mmHg}$. The mean 24-h SBP was $127 \pm 16 \mathrm{mmHg}$ and mean 24 -h DBP was $78 \pm 24$ mmHg. The mean eGFR of the study participants was $83 \pm 33$ $\mathrm{ml} / \mathrm{min} / 1.73 \mathrm{~m}^{2}$ (MDRD-4).

\section{Comparison of patients with} and without hypertension

The comparison of patients with and without hypertension is shown in Table 2. According to definition of hypertension (patients with office BP $\geq 140 / 90$ $\mathrm{mmHg}$ and/or previously diagnosed hypertension and/ or the use of antihypertensive medication), 853 (81\%) of all participants were identified as hypertensive. The mean age of hypertensive patients was significantly higher than nonhypertensive patients $(56 \pm 15$ vs. $49 \pm 15, p<0.0001)$. Hypertension was more common among females $(p=0.009)$. The rates of history of HL, DM and CKD among hypertensive patients were significantly higher than those among non-hypertensive patients (33.6\% vs. $14.2 \%, 21.9 \%$ vs. $7.6 \%, 30 \%$ vs. $3.5 \%$, respectively, $\mathrm{p}<0.0001$ ). There was no difference between two groups with respect to active smoking status (self-reported) and BMI (11.2\% vs. $16.2 \%, 28 \pm 5$ vs. $28 \pm 5$, respectively, $\mathrm{p}>0.05$ ). In patients with hypertension, the mean office SBP and DBP were significantly higher than those without hypertension $(144 \pm 20 \mathrm{mmHg}$ vs. $123 \pm 12 \mathrm{mmHg}, 89 \pm 28 \mathrm{mmHg}$ vs. $79 \pm 9 \mathrm{mmHg}$, respectively, $\mathrm{p}<0.0001)$.

\section{ABP phenotypes of patients with or without hypertension}

Among patients with hypertension, ABPM results showed that 388 (45\%) patients had SHT, 92 (11\%) had MHT, and 144 (17\%) had WCHT, whereas 229 (27\%) had SNT. Among patients without hypertension, $26(13 \%)$ of patients had MHT and none of those patients was on antihypertensive treatment. There was no difference in terms of MHT among hypertensive and non-hypertensive patients $(11 \%$ vs. $13 \%$, p>0.05). The rate of reverse dipper was higher among hypertensive patients compared with non-hypertensive (17\% vs. $8 \%, \mathrm{p}=0.002$ ) (Table 2).

Among patients with hypertension, $70 \%$ of those patients were taking antihypertensive treatment and only $27 \%$ of them had BP under control. The majority has been receiving with one or more drugs (one drug: $23.4 \%$ vs. 2 drugs: $22.8 \%$ vs. 3 or more drugs: $22.1 \%$ ). The percentages of patients taking antihypertensive drugs were ACEi $(20.6 \%)$, ARBs $(36.8 \%)$, CCBs (38.2\%), $\alpha$-blockers (18\%), $\beta$-blockers (32.5\%), CAAs $(0.5 \%)$ and diuretics $(30 \%)$. The

Table 1. The characteristics of the study population. Abbreviations: SD, standard deviation; BMI, body mass index; HT, hypertension; HL, hyperlipidemia; DM, diabetes mellitus; CKD, chronic kidney disease; SBP, systolic blood pressure; DPB, diastolic blood pressure; ABPM, ambulatory blood pressure monitoring; eGFR, estimated glomerular filtration rate; MDRD, modification of diet in renal disease. All values are shown as mean \pm standard deviation or as a case number

\begin{tabular}{lc} 
Patient's characteristics & Results \\
\hline Age (years) (mean \pm SD) & $55 \pm 15$ \\
Gender (n, male/female) & $445 / 608$ \\
BMI (kg/m²) (mean \pm SD) & $28 \pm 5$ \\
History of HT (n,+/-) & $702 / 351$ \\
History of HL (n,+/-) & $304 / 710$ \\
History of DM (n,+/-) & $200 / 841$ \\
History of CKD (n,+/-/renal transplantation) & $240 / 774 / 12$ \\
Salt restricted diet (self-reported) (n,+/-) & $361 / 612$ \\
Smoking status (self-reported) (n,+/-) & $117 / 844$ \\
Antihypertensive medication (n,+/-) & $588 / 465$ \\
Dipper/Nondipper/Reverse dipper & $449 / 444 / 160$ \\
Office SBP (mmHg) (mean $\pm S D)$ & $140 \pm 20$ \\
Office DBP (mmHg) (mean $\pm S D)$ & $87 \pm 25$ \\
Average 24-h ABPM SBP (mmHg) (mean $\pm S D)$ & $127 \pm 16$ \\
Average 24-h ABPM DBP (mmHg) (mean $\pm S D)$ & $78 \pm 24$ \\
Average 24-h ABPM daytime SBP (mmHg) (mean $\pm S D)$ & $130 \pm 16$ \\
Average 24-h ABPM daytime DBP (mmHg) (mean $\pm S D)$ & $79 \pm 11$ \\
Average 24-h ABPM nighttime SBP (mmHg) (mean $\pm S D)$ & $121 \pm 17$ \\
Average 24-h ABPM nighttime DBP (mmHg) (mean $\pm S D)$ & $72 \pm 11$ \\
eGFR (MDRD) (ml/min/1.73m 2 ) (mean $\pm S D)$ & $83 \pm 33$ \\
\hline & \\
\hline & \\
\hline & \\
\hline
\end{tabular}




\section{Kidney \\ Blood Pressure Research}

Table 2. Comparison of characteristics of hypertensive and non-hypertensive patients. Abbreviations: SD, standard deviation; BMI, body mass index; HL, hyperlipidemia; DM, diabetes mellitus; CKD, chronic kidney disease; SBP, systolic blood pressure; DPB, diastolic blood pressure; BP, blood pressure; ABPM, ambulatory blood pressure monitoring; ACEi, angiotensin-converting enzyme inhibitors; ARBs, angiotensin receptor blockers; CCBs, calcium channel blockers; CAAs, central acting agents; eGFR, estimated glomerular filtration rate; MDRD, modification of diet in renal disease. All values are shown as mean \pm standard deviation or as a case number or percentage. *p-value is based on 2-sample t test. **p-value is based on Pearson's chi-square or Fischer exact tests

\begin{tabular}{|c|c|c|c|}
\hline Parameters & Hypertension (+) n:853 (\%81) & $\begin{array}{c}\text { Hypertension (-) } \\
\text { n:200 (\%19) }\end{array}$ & $P$ value \\
\hline Age (years) (mean \pm SD) & $56 \pm 15$ & $49 \pm 15$ & $<0.0001^{*}$ \\
\hline Gender (n, \%) (male/female) & $377 / 476(44 \% / 56 \%)$ & 68/132 (34\%/66\%) & $0.009^{* *}$ \\
\hline BMI $\left(\mathrm{kg} / \mathrm{m}^{2}\right)($ mean $\pm \mathrm{SD})$ & $28 \pm 5$ & $28 \pm 5$ & $>0.05^{*}$ \\
\hline History of HL $(\mathrm{n},+)(\%)$ & $277(33.6 \%)$ & $27(14.2 \%)$ & $<0.0001^{* *}$ \\
\hline History of DM $(n,+)(\%)$ & $185(22 \%)$ & $15(7.6 \%)$ & $<0.0001^{* *}$ \\
\hline History of CKD $(n,+)(\%)$ & $233(27.6 \%)$ & $7(3.5 \%)$ & $<0.0001^{* *}$ \\
\hline Salt restricted diet (self-reported) $(n,+)(\%)$ & $341(43.7 \%)$ & $20(10.4 \%)$ & $<0.0001^{* *}$ \\
\hline Smoking status (self-reported) $(\mathrm{n},+)(\%)$ & $86(11.2 \%)$ & $31(16.2 \%)$ & $>0.05^{* *}$ \\
\hline Office SBP (mmHg) (mean \pm SD) & $144 \pm 20$ & $123 \pm 12$ & $<0.0001^{*}$ \\
\hline Office DBP (mmHg) (mean \pm SD) & $89 \pm 28$ & $79 \pm 9$ & $<0.0001^{*}$ \\
\hline \multicolumn{4}{|l|}{ ABPM results $(n, \%)$} \\
\hline - Sustained normotensive & $229(27 \%)$ & $165(82 \%)$ & $<0.0001^{* *}$ \\
\hline - Sustained hypertensive & $388(45 \%)$ & $6(3 \%)$ & $<0.0001^{* *}$ \\
\hline - Masked hypertensive & $92(11 \%)$ & $26(13 \%)$ & $>0.05^{* *}$ \\
\hline - White-coat hypertensive & $144(17 \%)$ & $3(2 \%)$ & $<0.0001^{* *}$ \\
\hline \multicolumn{4}{|l|}{ Status of nocturnal fall of BP } \\
\hline - $\quad$ Dipper (n, \%) & $359(42 \%)$ & $90(45 \%)$ & $>0.05^{* *}$ \\
\hline - $\quad$ Nondipper $(\mathrm{n}, \%)$ & $350(41 \%)$ & $94(47 \%)$ & $>0.05^{* *}$ \\
\hline - $\quad$ Reverse dipper $(\mathrm{n}, \%)$ & $144(17 \%)$ & $16(8 \%)$ & $0.002^{* *}$ \\
\hline \multicolumn{4}{|l|}{ Antihypertensive medication (n, \%) } \\
\hline - ACEi & $153(20.6 \%)$ & & \\
\hline - $\mathrm{ARBs}$ & $273(36.8 \%)$ & & \\
\hline - $\mathrm{CCBs}$ & $283(38.2 \%)$ & & \\
\hline - Diuretics & $223(30 \%)$ & & \\
\hline - $\quad \beta$-blockers & $240(32.4 \%)$ & & \\
\hline - $\alpha$-blockers & $134(18 \%)$ & & \\
\hline - CAAs & $4(0.5 \%)$ & & \\
\hline - Single-pill combination & $228(30.8 \%)$ & & \\
\hline eGFR (MDRD) $\left(\mathrm{ml} / \mathrm{min} / 1.73 \mathrm{~m}^{2}\right)($ mean $\pm S D)$ & $79 \pm 33$ & $102 \pm 26$ & $<0.0001^{*}$ \\
\hline
\end{tabular}

rate of patients using single-pill combination was 30.8\%. The most frequently prescribed single-pill combination was ARBs + diuretics (21.6\%). The mean eGFR among hypertensive patients was less than those among non-hypertensive patients $\left(79 \pm 33 \mathrm{ml} / \mathrm{min} / 1.73 \mathrm{~m}^{2}\right.$ vs. $102 \pm 26 \mathrm{ml} / \mathrm{min} / 1.73 \mathrm{~m}^{2}, \mathrm{p}<0.0001$ ) (Table 2 ).

Differences in clinical and laboratory parameters among four groups of ABP phenotypes According to office BP and ABPM results, patients were divided into 4 groups as listed below: Group $1(\mathrm{n}=394,37.5 \%)$ was composed of patients with SNT;

Group 2 ( $n=394,37.5 \%)$ was composed of patients with SHT;

Group 3 (n=118, 11\%) was composed of patients with MHT;

Group $4(\mathrm{n}=147,14 \%)$ was composed of patients with WCHT.

The comparative clinical and laboratory parameters of groups are given in Table 3 . Patients with MHT were significantly older compared to patients with SNT ( $58 \pm 15$ vs. $53 \pm 15$, $\mathrm{p}=0.025)$. The prevalence of SHT was higher in men than women, whereas the prevalence of WCHT was higher in women than men $(\mathrm{p}<0.0001)$. There was no significant difference between 4 groups with regard to BMI $(\mathrm{p}=0.142)$, a history of DM $(\mathrm{p}=0.189)$ and smoking status (self-reported) ( $\mathrm{p}=0.306)$. Patients with SHT had the highest prevalence of history of hypertension, HL and CKD $(\mathrm{p}<0.0001)$. Also, the use of antihypertensive medication and implementation of salt-restricted diet were statistically higher in patients with SHT $(p<0.0001)$. eGFR levels were not different among the groups $(p>0.05)$. In patients receiving 


\section{Kidney Blood Pressure Research}

antihypertensive medication, the rates of MHT and WCHT patients were $12.8 \%$ and $13.6 \%$, respectively. The rate of hypertension control was $31.3 \%$.

\section{Comparison of office BP and ABPM results among four groups}

Comparison of office BP and ABPM results among patients with SNT, SHT, MHT, and WCHT are presented in Table 3. In patients with MHT, office SBP was significantly lower than SHT patients and WCHT patients $(128 \pm 10.5 \mathrm{mmHg}$ vs. $157 \pm 16 \mathrm{mmHg}$ vs. $151 \pm 13.5$ $\mathrm{mmHg}, \mathrm{p}<0.0001)$, but it was significantly higher than SNT patients $(128 \pm 10.5 \mathrm{mmHg}$ vs. $124 \pm 13 \mathrm{mmHg}, \mathrm{p}=0.029$ ). The office DBP of MHT patients was also significantly lower than SHT patients and WCHT patients $(81 \pm 9 \mathrm{mmHg}$ vs. $97 \pm 38 \mathrm{mmHg}$ vs. $92 \pm 9 \mathrm{mmHg}, \mathrm{p}<0.0001)$, while there was no significant difference between MHT and SNT patients $(81 \pm 9 \mathrm{mmHg}$ vs. $78 \pm 9 \mathrm{mmHg}, \mathrm{p}>0.05)$. Average ambulatory 24-h, daytime and nighttime SBP levels were different among 4 groups of patients $(\mathrm{p}<0.0001)$. Average ambulatory $24-\mathrm{h}$, daytime and nighttime DBP levels were not different in patients with SNT and WCHT ( $>00.05)$. Also, average ambulatory 24-h and nighttime DBP levels were not different between SHT and MHT patients $(\mathrm{p}>0.05)$.

\section{Characteristics of nocturnal BP change}

Comparison of fall of nocturnal BP among patients with SNT, SHT, MHT, and WCHT showed that dipper, nondipper and reverse dipper were significant differences among groups (Table 4). Prevalence of reverse dipper pattern was significantly higher in patients with SHT than other groups $(\mathrm{p}<0.0001)$.

Table 3. Clinical and laboratory parameters among four groups of patients according to ABP phenotypes. Abbreviations: SD, standard deviation; BMI, body mass index; eGFR, estimated glomerular filtration rate; MDRD, modification of diet in renal disease; HT, hypertension; HL, hyperlipidemia; DM, diabetes mellitus; CKD, chronic kidney disease; SBP, systolic blood pressure; DPB, diastolic blood pressure; ABP, ambulatory blood pressure; ABPM, ambulatory blood pressure monitoring. All values are shown as mean \pm standard deviation or as a case number. *p-value is based on one way ANOVA test. **p-value is based on Pearson's chi-square or Fischer exact tests. Groups with significant differences according to the Benferroni corrected Mann-Whitney U-test are depicted in superscript roman

\begin{tabular}{|c|c|c|c|c|c|}
\hline Parameters & $\begin{array}{c}\text { Group I (SNT } \\
\text { patients) }(\mathrm{n}=394)\end{array}$ & $\begin{array}{c}\text { Group II (SHT } \\
\text { patients) }(\mathrm{n}=394)\end{array}$ & $\begin{array}{c}\text { Group III (MHT } \\
\text { patients) }(\mathrm{n}=118)\end{array}$ & $\begin{array}{l}\text { Group IV (WCHT } \\
\text { patients) }(\mathrm{n}=147)\end{array}$ & $P$ value \\
\hline Age (years) (mean \pm SD) & $53 \pm 15^{\text {III }}$ & $56 \pm 15$ & $58 \pm 15^{\mathrm{I}}$ & $55 \pm 17$ & $0.017^{*}$ \\
\hline Gender ( $\mathrm{n}$, male/female) & $129 / 265^{\text {II,III }}$ & $206 / 188^{I}$ & $59 / 59 \mathrm{ll}, \mathrm{VV}$ & $51 / 96^{\text {III }}$ & $<0.0001^{* *}$ \\
\hline BMI $\left(\mathrm{kg} / \mathrm{m}^{2}\right)($ mean $\pm \mathrm{SD})$ & $28 \pm 5$ & $28 \pm 5$ & $26 \pm 5$ & $29 \pm 5$ & $>0.05^{*}$ \\
\hline History of HT $(n,+/-)$ & $221 / 173^{\mathrm{II}, \mathrm{III}}$ & $294 / 100^{\mathrm{I}}$ & $91 / 27^{\mathrm{I}, \mathrm{IV}}$ & $96 / 51^{\mathrm{III}}$ & $<0.0001^{* *}$ \\
\hline History of HL $(n,+/-)$ & $86 / 291 \mathrm{III,IV}$ & $115 / 268$ & $38 / 79 \mathrm{IIV}$ & $65 / 72^{\mathrm{I}, \mathrm{III}}$ & $<0.0001^{* *}$ \\
\hline History of DM $(\mathrm{n},+/-)$ & $62 / 328$ & $81 / 308$ & $24 / 94$ & $33 / 111$ & $>0.05^{* *}$ \\
\hline $\begin{array}{l}\text { History of CKD }(n,+/-/ \text { renal } \\
\text { transplantation) }\end{array}$ & $62 / 321 / 4 \mathrm{II}, \mathrm{III}$ & $114 / 257 / 10^{1}$ & $36 / 80 / 2^{1}$ & $28 / 116 / 1$ & $<0.0001^{* *}$ \\
\hline $\begin{array}{l}\text { Salt restricted diet (self-reported) } \\
(\mathrm{n},+/-)\end{array}$ & $110 / 264$ II,III & $150 / 219$ & $55 / 56^{1}$ & $46 / 73$ & $<0.0001^{* *}$ \\
\hline $\begin{array}{l}\text { Smoking status (self-reported) } \\
(\mathrm{n},+/-)\end{array}$ & $41 / 328$ & $53 / 310$ & $10 / 102$ & $13 / 104$ & $>0.05^{* *}$ \\
\hline $\begin{array}{l}\text { Antihypertensive medication } \\
(\mathrm{n},+/-)\end{array}$ & $184 / 210^{\mathrm{II}, \mathrm{III}}$ & $249 / 145^{\mathrm{I}}$ & $75 / 43^{1}$ & $80 / 67$ & $<0.0001^{* *}$ \\
\hline Office SBP (mmHg) $($ mean \pm SD) & $124 \pm 13^{\mathrm{II}, \mathrm{II}, \mathrm{IV}}$ & $157 \pm 16^{\mathrm{L}, \mathrm{III}, \mathrm{IV}}$ & $128 \pm 10.5 \mathrm{I}, \mathrm{II}, \mathrm{IV}$ & $151 \pm 13.5^{\mathrm{I}, \mathrm{II}, \mathrm{III}}$ & $<0.0001^{*}$ \\
\hline Office DBP $(\mathrm{mmHg})($ mean \pm SD) & $78 \pm 9 \mathrm{II}, \mathrm{IV}$ & $97 \pm 38$ I,III & $81 \pm 9 \mathrm{II}, \mathrm{IV}$ & $92 \pm 9 \mathrm{IIIII}$ & $<0.0001^{*}$ \\
\hline $\begin{array}{l}\text { Average 24-h ABPM SBP (mmHg) } \\
(\text { mean } \pm \text { SD) }\end{array}$ & $114 \pm 8^{\mathrm{II}, \mathrm{III}, \mathrm{IV}}$ & $142 \pm 12^{1, \mathrm{III}, \mathrm{VV}}$ & $132 \pm 9 \mathrm{I}, \mathrm{II}, \mathrm{IV}$ & $120 \pm 7 \mathrm{I}, \mathrm{II}, \mathrm{III}$ & $<0.0001^{*}$ \\
\hline $\begin{array}{l}\text { Average 24-h ABPM DBP }(\mathrm{mmHg}) \\
(\text { mean } \pm \text { SD) }\end{array}$ & $72 \pm 37 \mathrm{II}, \mathrm{III}$ & $84 \pm 10^{\mathrm{I}, \mathrm{IV}}$ & $81 \pm 7 \mathrm{l}, \mathrm{IV}$ & $72 \pm 6$ II,III & $<0.0001^{*}$ \\
\hline $\begin{array}{l}\text { Average 24-h ABPM daytime SBP } \\
(\mathrm{mmHg})(\text { mean } \pm \text { SD })\end{array}$ & $118 \pm 9 \mathrm{II}, \mathrm{III}, \mathrm{IV}$ & $145 \pm 12^{1, \mathrm{III}, \mathrm{IV}}$ & $133 \pm 9 \mathrm{I}, \mathrm{II}, \mathrm{IV}$ & $123 \pm 8^{\mathrm{I}, \mathrm{II}, \mathrm{III}}$ & $<0.0001^{*}$ \\
\hline $\begin{array}{l}\text { Average 24-h ABPM daytime DBP } \\
(\mathrm{mmHg})(\text { mean } \pm \mathrm{SD})\end{array}$ & $73 \pm 6^{I I, I I I I}$ & $87 \pm 11^{\mathrm{L}, \mathrm{III}, \mathrm{IV}}$ & $83 \pm 8$ IIII,IV & $74 \pm 7 \mathrm{II}, \mathrm{III}$ & $<0.0001^{*}$ \\
\hline $\begin{array}{l}\text { Average 24-h ABPM nighttime SBP } \\
(\mathrm{mmHg})(\text { mean } \pm \mathrm{SD})\end{array}$ & $108 \pm 91 \mathrm{II}, \mathrm{III}, \mathrm{IV}$ & $135 \pm 15^{1, \mathrm{III}, \mathrm{V}}$ & $128 \pm 13^{\mathrm{I}, \mathrm{III}, \mathrm{IV}}$ & $114 \pm 11^{1, \mathrm{II}, \mathrm{III}}$ & $<0.0001^{*}$ \\
\hline $\begin{array}{l}\text { Average 24-h ABPM nighttime } \\
\text { DBP (mmHg) (mean } \pm \text { SD) }\end{array}$ & $65 \pm 6^{\mathrm{II}, \mathrm{III}}$ & $79 \pm 11^{1, I V}$ & $77 \pm 8 \mathrm{l}, \mathrm{IV}$ & $67 \pm 8^{1 \mathrm{IIIII}}$ & $<0.0001^{*}$ \\
\hline eGFR (MDRD) (ml $\left./ \mathrm{min} / 1.73 \mathrm{~m}^{2}\right)$ & $87.5 \pm 31$ & $78 \pm 34$ & $84 \pm 37$ & $84 \pm 35$ & $>0.05^{*}$ \\
\hline
\end{tabular}




\section{Kidney Blood Pressure Research}

Table 4. Characteristics of nocturnal BP change among four groups. Abbreviations: BP, blood pressure; SNT, sustained normotensive; SHT, sustained hypertensive; MHT, masked hypertensive; WCHT, white-coat hypertensive. All values are shown as a case number or percentage. *p-value is based on Pearson's chisquare or Fischer exact tests. Groups with significant differences according to the Benferroni corrected Mann-Whitney U-test are depicted in superscript roman

\begin{tabular}{|c|c|c|c|c|c|}
\hline $\begin{array}{l}\text { Status of nocturnal BP } \\
\text { change }\end{array}$ & $\begin{array}{c}\text { Group I (SNT patients) } \\
\text { (n:394) }\end{array}$ & $\begin{array}{c}\text { Group II (SHT } \\
\text { patients) (n:394) }\end{array}$ & $\begin{array}{l}\text { Group III (MHT } \\
\text { patients) (n:118) }\end{array}$ & $\begin{array}{l}\text { Group IV (WCHT } \\
\text { patients) (n:147) }\end{array}$ & $P$ value \\
\hline Dipper (n, \%) & $182(40.5 \%)^{I I I, I V}$ & $168(37.5)^{\mathrm{III,IV}}$ & $32(7 \%)^{1,11}$ & $67(15 \%)^{\mathrm{L}, 11}$ & $<0.0001^{*}$ \\
\hline Nondipper (n, \%) & $173(39 \%)^{\mathrm{III}, \mathrm{IV}}$ & $164(37 \%)^{\mathrm{III}, \mathrm{IV}}$ & $48(11 \%)^{\mathrm{I}, \mathrm{II}}$ & $59(13 \%)^{\mathrm{L}, \mathrm{II}}$ & $<0.0001^{*}$ \\
\hline Reverse dipper (n, \%) & $39(24 \%)^{\mathrm{II}}$ & $62(39 \%)^{1, I I I, I V}$ & $38(24 \%)^{\mathrm{II}}$ & $21(13 \%)^{\mathrm{II}}$ & $<0.0001^{*}$ \\
\hline
\end{tabular}

\section{Discussion}

In the current study, a total of 851 study participants (81\%) were hypertensive and the prevalence of hypertension was more common among females $(p=0.009)$. The mean age of hypertensive patients was higher than non-hypertensive $(\mathrm{p}<0.0001)$. The presence of traditional cardiovascular risk factors such as HL, DM, CKD was higher in patients with hypertension $(p<0.0001)$, but no remarkable difference was observed in terms of the smoking status (self-reported) and BMI among patients with hypertension and without ( $p>0.05$ ). According to the ABPM results in patients with hypertension, our study showed that $11 \%$ of patients had MHT, $17 \%$ had WCHT, and $45 \%$ had SHT, while $27 \%$ had well controlled BP. We also found that patients with hypertension had the high rate of reverse dipper pattern compared to patients without hypertension $(17 \%$ vs $8 \%, p=0.002)$. We also found that the prevalence of MHT patients was 11\%, whereas that of WCHT patients was $14 \%$. We observed that patients with MHT was older than other three groups and it was significant only compared to SNT patients $(\mathrm{p}=0.025)$. We also found that SHT was more common in men, whereas WCHT in women $(\mathrm{p}<0.0001)$. Our data showed that there was no significant difference in eGFR among patients with SNT, SHT, MHT and WCHT. Nocturnal BP patterns (dipper, nondipper and reverse dipper) were significantly different among four groups. Particularly, reverse dipper pattern was high in patients with SHT.

ABPM is becoming increasingly important for evaluation of hypertension. Compared with office BP measurement, ABPM provides more accurate assessment of BP and prediction of cardiovascular outcomes [10]. The growing use of ABPM has led to identification of abnormal ABP phenotypes and high BP variability. Thus, it allows the recognition of individual risk profile of patients. It can be helpful in identifying patients at increased risk of developing sustained hypertension and cardiovascular events [11]. Also, elevated BP variability during ABPM is associated with increased risk of cardiovascular events, cerebral and renal damage $[12,13]$.

However, the clinical relevance of WCHT and MHT is debatable. In a meta-analysis conducted in 2011 about the prognostic significance of WCHT and MHT diagnosed by ABPM, showed that the cardiovascular risk was not significantly different between WCHT and normotensive patients. In the same study, compared to normotensive patients, MHT, WCHT and SHT were associated with increased risk for adverse clinical outcomes [14]. In other studies, Cuspidi et al. [15] and Tadic et al. [16] demonstrated the harmful effects of white coat on heart in patients with WCHT. In another meta-analysis performed by Briasoulis et al., WCHT was associated with higher rates of cardiovascular morbidity and mortality compared with normotensive patients, but not significantly different in all-cause mortality and stroke risk [17].

The prevalence of WCHT and MHT are varying based on patient characteristics and study population. Risk factors related to WCHT are age, female sex and non-smoking status. Male sex, relatively younger age, being smoker, alcohol consumption, stress, increased physical activity, high salt intake and the presence of diabetes, obesity and kidney disease were found to be associated with MHT [18-20]. Therefore, the identification of WCHT and 


\section{Kidney Blood Pressure Research}

Kidney Blood Press Res 2018;43:690-700

\begin{tabular}{l|l}
\hline DOI: $10.1159 / 000489742$ & (C) 2018 The Author(s). Published by S. Karger AG, Basel
\end{tabular}

Published online: 16 May, 2018

www.karger.com/kbr

697

MHT patients via ABPM is important in patients with high cardiovascular risk profiles to provide a proper management of those patients. In our study population, we did not evaluate target organ damage. Based on ABP phenotypes, among patients with SNT, SHT, MHT and WCHT, we did not find significant differences in smoking status, presence of diabetes, eGFR and BMI. We found that patients with MHT were older and WCHT was more common in women. Our results showed that the rates of MHT and WCHT patients in diabetics were $12 \%$ and $16.5 \%$, respectively. In patients with CKD the prevalence of MHT was 15\%, while that of WCHT was $11 \%$. In addition to clinical determinants of cardiovascular risk factors, ABPM provides a comprehensive assessment of BP profile and adds prognostic information on the development of cardiovascular events in high-risk hypertensive patients. Hence, in high risk individuals ABPM should be kept in mind [21].

Several studies examining the relationship between circadian BP patterns and cardiovascular risk, were shown not only an increase target organ damage and cardiovascular events, but also predictor of cardiovascular risk in both hypertensive and normotensive patients [22-24]. In the present study, among patients with hypertension, nondipper BP pattern was found in 350 (41\%) patients. In addition, among patients without hypertension, $94(47 \%)$ had nondipper. Also we found that the rate of reverse dipper pattern was significantly higher in patients with hypertension than those without hypertension. We also found that there were significant differences with regard to different nocturnal BP patterns (dipper, nondipper and reverse dipper) among patients with various ABP phenotypes (SNT, SHT, MHT and WCHT). The use of ABPM provides information on circadian BP pattern and it may also predict prognosis related to target organ damage and cardiovascular outcomes.

In the last years, current guidelines have defined the use of ABPM for the management of hypertension in clinical practice. In 2013, the European Society of Hypertension (ESH) / European Society of Cardiology (ESC) guidelines recommended both ABPM and home BP measurement as an adjunct to office BP measurement [8]. In addition, in the 2013 ESH/ESC guideline, specific indications for ABPM were as follows: (i) marked discordance between office $\mathrm{BP}$ and home BP; (ii) assessment of dipping status; (iii) suspicion of nocturnal hypertension or absence of dipping, such as in patients with sleep apnea, CKD, or DM; (iv) assessment of BP variability. The ESH Working Group on Blood Pressure Monitoring and Cardiovascular Variability published a new consensus document for ABPM in 2014, and presented an up to date summary of the clinical indications for the use of ABPM in daily practice [9]. The National Institute for Health and Care Excellence (NICE) guidelines recommended the use of ABPM to confirm diagnosis of hypertension if the clinic BP of 140/90 mm Hg or higher [25]. In contrast, the guidelines of the American Eighth Joint National Committee (JNC 8) did not mention on ABPM [26]. The National Heart Foundation of Australia's Guideline for the diagnosis and management of hypertension in adults recommended that ABPM and/or home BP monitoring, if clinic BP is $\geq 140 / 90 \mathrm{mmHg}$ or hypertension is suspected [27]. The Hypertension Canada's 2017 Guidelines recommends that the out-of-office BP assessment should preferably be done by ABPM, if the office BP readings are elevated [28].

In Turkey, the Turkish Hypertension Consensus Report has been published in 2015 in order to create a standardized approach to diagnosis and treatment of hypertension in adults. In this report, it has been suggested that if the clinic BP is $\geq 140 / 90 \mathrm{mmHg}$, the diagnosis of hypertension must be confirmed by repeated clinical BP measurements and/ or whenever possible by ABPM or home BP measurements [29]. However, according to the results of a recent nationwide field survey in Turkey, the prevalence of ownership of a home sphygmomanometer among hypertensive subjects was found as $20.1 \%$, and the usage of wrist devices and non-validated devices were common [30]. Home BP monitoring is not a viable option until the implementation of a hypertension care program consisting of reimbursement of a validated sphygmomanometer in Turkey.

Although the above consensus report emphasizes the importance of ABPM for the management of patients with hypertension, ABPM cannot be also adequately implemented in clinical practice due to limited availability of ABPM devices in many clinical settings in 


\section{Kidney \\ Blood Pressure Research}

Kidney Blood Press Res 2018;43:690-700
\begin{tabular}{l|l}
\hline DOI: 10.1159/000489742 & $\begin{array}{l}\text { (c) 2018 The Author(s). Published by S. Karger AG, Basel } \\
\text { www.karger.com/kbr }\end{array}$ \\
Published online: 16 May, 2018 &
\end{tabular}

Erdogmus et al.: Clinical Characteristics of Ambulatory Blood Pressure Phenotypes

Turkey. Numerous researches over past three decades have established ABPM as an evidencebased and cost-effective gold-standard for the diagnosis and treatment of hypertension. But, if the resources and its availability are limited, ABPM is recommended only marked discordance between clinical BP and home BP, assessment of dipping status, suspicion of nocturnal hypertension and assessment of BP variability [29]. Potential usages for ABPM in our country may include screening of individuals who have traditional cardiovascular risk factors. Use of ABPM can reduce misdiagnosis, and unnecessary treatment, and lead to better control of BP. Clinicians should use ABPM whenever possible and take initiatives to establish ABPM services where those do not exist. However, if ABPM is to be widely used in general practice, there is a need to establish appropriate educational activities and to improve the methods of presenting and analyzing ABPM results in a national program for hypertension.

This study has some limitations. The major limitations of our study were its retrospective design and partially based on self-reported data on comorbidities. Other limitation of the study was that the patients were diagnosed abnormal ABP phenotypes based on a single ABPM. Another limitation of the study was the lack of data on hypertensive end-organ damage, such as those for retinopathy, albuminuria, changes in the vasculature, and lack of echocardiography findings.

\section{Conclusion}

Potential usages for ABPM in Turkey may include screening of high risk individuals who have traditional cardiovascular risk factors. Future studies are needed to clarify the risk factors of different $\mathrm{ABP}$ phenotypes and to evaluate the role of $\mathrm{ABPM}$ on detection and control of hypertension. There is also a need for standardization protocol for indications of ABPM in low and middle income countries with limited availability of ABPM devices.

\section{Acknowledgements}

The Turkish Society of Hypertension and Renal Diseases, a nonprofit national organization in Turkey, supported the publications costs for this article.

\section{Disclosure Statement}

All authors declare that they have no conflicts of interest.

\section{References}

1 Kearney PM, Whelton M, Reynolds K, Muntner P, Whelton PK, He J: Global burden of hypertension: analysis of worldwide data. Lancet 2005;365:217-223.

-2 Lim SS, Vos T, Flaxman AD, Danaei G, Shibuya K, Adair-Rohani H, Amann M, Anderson HR, Andrews KG, Aryee M, Atkinson C, Bacchus LJ, Bahalim AN, Balakrishnan K, Balmes J, Barker-Collo S, Baxter A, Bell ML, Blore JD, Blyth F, et al.: A comparative risk assessment of burden of disease and injury attributable to 67 risk factors and risk factor clusters in 21 regions, 1990-2010: a systematic analysis for the Global Burden of Disease Study 2010. Lancet. 2012;380:2224-2260.

-3 Altun B, Arici M, Nergizoğlu G, Derici U, Karatan O, Turgan C, Sindel S, Erbay B, Hasanoğlu B, Cağlar S: Turkish Society of Hypertension and Renal Diseases. Prevalence, awareness, treatment and control control of hypertension in Turkey (the PatenT study) in 2003. J Hypertens 2005;23:1817-1823. 


\section{Kidney \\ Blood Pressure Research}

-4 Sengul S, Akpolat T, Erdem Y, Derici U, Arici M, Sindel S, Karatan O, Turgan C, Hasanoglu E, Caglar S, Erturk S: Turkish Society of Hypertension and Renal Diseases. Changes in hypertension prevalence, awareness, treatment, and control rates in Turkey from 2003 to 2012. J Hypertens 2016;34:1208-1217.

-5 Pickering TG, Shimbo D, Haas D: Ambulatory blood-pressure monitoring. N Engl J Med 2006;354:23682374.

6 Angeli F, Reboldi G, Poltronieri C, Bartolini C, D’Ambrosio C, de Filippo V, Verdecchia P: Clinical utility of ambulatory blood pressure monitoring in the management of hypertension. Expert Rev Cardiovasc Ther 2014;12:623-634.

-7 Levey AS, Bosch JP, Lewis JB, Greene T, Rogers N, Roth D: A more accurate method to estimate glomerular filtration rate from serum creatinine: a new prediction equation. Modification of Diet in Renal Disease Study Group. Ann Intern Med 1999;130:461-470.

-8 Mancia G, Fagard R, Narkiewicz K, Redón J, Zanchetti A, Böhm M, Christiaens T, Cifkova R, De Backer G, Dominiczak A, Galderisi M, Grobbee DE, Jaarsma T, Kirchhof P, Kjeldsen SE, Laurent S, Manolis AJ, Nilsson PM, Ruilope LM, Schmieder RE,et al.: 2013 ESH/ESC Guidelines for the management of arterial hypertension: the Task Force for the management of arterial hypertension of the European Society of Hypertension (ESH) and of the European Society of Cardiology (ESC). J Hypertens 2013;31:1281-1357.

-9 Parati G, Stergiou G, O’Brien E, Asmar R, Beilin L, Bilo G, Clement D, de la Sierra A, de Leeuw P, Dolan E, Fagard R, Graves J, Head GA, Imai Y, Kario K, Lurbe E, Mallion JM, Mancia G, Mengden T, Myers M, et al.: European Society of Hypertension Working Group on Blood Pressure Monitoring and Cardiovascular Variability. European Society of Hypertension practice guidelines for ambulatory blood pressure monitoring. J Hypertens 2014;32:1359-1366.

10 Mancia G, Verdecchia P: Clinical value of ambulatory blood pressure: evidence and limits. Circ Res 2015;116:1034-1045.

$>11$ Viera AJ, Shimbo D: Ambulatory blood pressure phenotypes and the risk for hypertension. Curr Hypertens Rep 2014;16:481.

12 Xie Z, Liao X, Yin W, Kang Y, Guo J, Lu M: Relationship Between Short-Term Blood Pressure Variability and Incidence of Acute Kidney Injury in Critically III Patients. Kidney Blood Press Res 2017;42:1238-1246.

13 Li W, Yu Y, Liang D, Jia EZ: Factors Associated with Blood Pressure Variability Based on Ambulatory Blood Pressure Monitoring in Subjects with Hypertension in China. Kidney Blood Press Res 2017;42:267-275.

14 Pierdomenico SD, Cuccurullo F: Prognostic value of white-coat and masked hypertension diagnosed by ambulatory monitoring in initially untreated subjects: an updated meta analysis. Am J Hypertens 2011;24:52-58.

15 Cuspidi C, Rescaldani M, Tadic M, Sala C, Grassi G, Mancia G: White-coat hypertension, as defined by ambulatory blood pressure monitoring, and subclinical cardiac organ damage: a meta-analysis. J Hypertens 2015;33:24-32.

16 Tadic M, Cuspidi C, Ivanovic B, Vukomanovic V, Djelic M, Celic V, Kocijancic V: The impact of White-Coat Hypertension on Cardiac Mechanics. J Clin Hypertens (Greenwich). 2016;18:617-622.

17 Briasoulis A, Androulakis E, Palla M, Papageorgiou N, Tousoulis D: White-coat hypertension and cardiovascular events: a meta-analysis. J Hypertens 2016;34:593-599.

$>18$ Pickering TG, Eguchi K, Kario K: Masked hypertension: a review. Hypertens Res 2007;30:479-488.

19 Kawano Y, Horio T, Matayoshi T, Kamide K: Masked hypertension: subtypes and target organ damage. Clin Exp Hypertens 2008;30:289-296.

20 Angeli F, Reboldi G, Verdecchia P: Masked hypertension: evaluation, prognosis, and treatment. Am J Hypertens 2010;23:941-948.

21 De la Sierra A, Banegas JR, Segura J, Gorostidi M, Ruilope LM: CARDIORISC Event Investigators. Ambulatory blood pressure monitoring and development of cardiovascular events in high-risk patients included in the Spanish ABPM registry: the CARDIORISC Event study. J Hypertens 2012;30:713-719.

22 De la Sierra A, Redon J, Banegas JR, Segura J, Parati G, Gorostidi M, de la Cruz JJ, Sobrino J, Llisterri JL, Alonso J, Vinyoles E, Pallarés V, Sarría A, Aranda P, Ruilope LM, Spanish Society of Hypertension Ambulatory Blood Pressure Monitoring Registry Investigators: Spanish Society of Hypertension Ambulatory Blood Pressure Monitoring Registry Investigators. Prevalence and factors associated with circadian blood pressure patterns in hypertensive patients. Hypertension 2009;53:466-472. 


\section{Kidney \\ Blood Pressure Research}

Kidney Blood Press Res 2018;43:690-700

\begin{tabular}{l|l}
\hline DOI: $10.1159 / 000489742$ & (c) 2018 The Author(s). Published by S. Karger AG, Basel
\end{tabular}

Published online: 16 May, 2018 www.karger.com/kbr

23 Cicconetti P, Donadio C, Pazzaglia MC, D’Ambrosio F, Marigliano V: [Circadian rhythm of blood pressure: non-dipping pattern and cardiovascular risk]. Recenti Prog Med 2007;98:401-406.

24 Campbell PT, White WB: Utility of ambulatory blood pressure monitoring for the management of hypertension. Curr Opin Cardiol 2017;32:365-372.

25 National Institute for Health and Care Excellence (NICE). Hypertension in adults: diagnosis and management. Clinical guideline 127.2011. https://www.nice.org.uk/guidance/CG127 (accessed 13 December, 2017).

-26 James PA, Oparil S, Carter BL, Cushman WC, Dennison-Himmelfarb C, Handler J, Lackland DT, LeFevre ML, MacKenzie TD, Ogedegbe 0, Smith SC Jr, Svetkey LP, Taler SJ, Townsend RR, Wright JT Jr, Narva AS, Ortiz E: 2014 evidence-based guideline for the management of high blood pressure in adults: report from the panel members appointed to the Eighth Joint National Committee (JNC 8). JAMA 2014;311:507-520.

27 Gabb GM, Mangoni AA, Anderson CS, Cowley D, Dowden JS, Golledge J, Hankey GJ, Howes FS, Leckie L, Perkovic V, Schlaich M, Zwar NA, Medley TL, Arnolda L: Guideline for the diagnosis and management of hypertension in adults - 2016. Med J Aust 2016;205:85-89.

28 Leung AA, Daskalopoulou SS, Dasgupta K, McBrien K, Butalia S, Zarnke KB, Nerenberg K, Harris KC, Nakhla M, Cloutier L, Gelfer M, Lamarre-Cliche M, Milot A, Bolli P, Tremblay G, McLean D, Tobe SW, Ruzicka M, Burns KD, Vallée M, et al.: Hypertension Canada's 2017 Guidelines for Diagnosis, Risk Assessment, Prevention, and Treatment of Hypertension in Adults. Can J Cardiol 2017;33:557-576.

-29 Arıcı M, Birdane A, Güler K, Yıldız BO, Altun B, Ertürk Ş, Aydoğdu S, Özbakkaloğlu M, Ersöz HÖ, Süleymanlar G, Tükek T, Tokgözoğlu L, Erdem Y; Türk Kardiyoloji Derneğ i (TKD), Türk İç Hastalıkları Uzmanlık Derneği (TIHUD), Türkiye Endokrinoloji ve Metabolizma Derneği (TEMD), Türk Nefroloji Derneği (TND), Türk Hipertansiyon ve Böbrek Hastalıkları Derneği.Turkish Hypertension Consensus Report. Turk Kardiyol Dern Ars 2015;43:402-409.

30 Akpolat T, Arici M, Sengul S, Derici U, Ulusoy S, Erturk S, Erdem Y. Home sphygmomanometers can help in the control of blood pressure: A nationwide field survey. Hypertension Res 2018; DOI: 10.1038/s41440018-0030-8. 